\title{
Praktikalitas penggunaan e-modul dalam pembelajaran nail art
}

\author{
Mutia Putri $^{\left.{ }^{*}\right)}$, Rahmiati Rahmiati ${ }^{1}$, Muharika Dewi ${ }^{1}$, Dedy Irfan ${ }^{1}$ \\ ${ }^{1}$ Fakultas Teknik, Universitas Negeri Padang, Indonesia
}

\section{Article Info \\ Article history: \\ Received Des $18^{\text {th }}, 2021$ \\ Revised Jan $20^{\text {th }}, 2022$ \\ Accepted Jan $31^{\text {th }}, 2022$}

\section{Keyword:}

Praktikalitas

E-Modul

Nail art

\begin{abstract}
Nail art banyak digandurungi oleh wanita zaman sekarang, banyaknya peminat ini perlunya ada perkembangan dalam dunia nail art. Perkembangan ini memancing untuk bisa lebih kreatif,dalam dunia pendidikan untuk memancing kreativitas mahasiswa maka diperlukan media pembelajaran yang reatif juga. Media pembelajaran yang digunakan adalah e-modul. Penelitian menggunakan penelitian pengembangan, imstrumen penelitian menggunakan anget dengan sampel dua orang dosen, tiga orang mahasiswa (kelompok kecil), sepuluh orang mahasiwa (kelompok besar). Hasil penelitian menjelaskan bahwa penggunaan e-modul dalam pembelajaran nail art oleh dosen sangat praktis, kelompok kecil menjawab sangat praktis dan kelompok besar menjawab praktis.
\end{abstract}

C 2022 The Authors. Published by IICET.

This is an open access article under the CC BY-NC-SA license

(https://creativecommons.org/licenses/by-nc-sa/4.0

\section{Corresponding Author:}

Putri, M.,

Fakultas Teknik, Universitas Negeri Padang, Indonesia

Email: mutiaputri1996@gmail.com

\section{Pendahuluan}

Perkembangan diera modern ini membuat semua aspek berkembang termasuk kecantikan. Banyak ahli kecantikan yang menciptakan ide-ide baru dari pemikiran sehingga menghasilkan sebuah seni di bidang kecantikan. Merias kuku (nail art) saat ini membawa pengaruh positif dalam dunia kecantikan. Perkembangan ini menuntut untuk selalu ada perubahan setiap waktu. Merias kuku memerlukan kreatifitas dengan menggunakan beberapa teknik sehingga menghasilkan karya seni yang indah. Kreativitas itu sendiri merupakan bentuk pemikiran yang imajinatif yang menghasilkan keaslian, kemurnian dan nilai tersendiri. Menurut Andiyana (2018:240) kreativitas adalah kemampuan berkarya sehingga mampu menciptakan penemuan baru yang unik serta memiliki arti. Orang yang memiliki sifat yang kreatif biasanya menerima perbedaan, memandang sesuatu dengan secara luas dan juga memiliki jiwa toleransi terhadap sesuatu yang tidak jelas. Untuk memancing kreativitas mahasiswa pendidik dituntut untuk selalu ada pembeharuan termasuk dalam media pembelajaran.

Pendidikan memerlukan media dalam pembelajaran, media pembelajaran membuat pelajar (mahasiswa) mampu memperoleh pengetahuan, keterampilan atau sikap. Pengertian ini dosen, buku teks dan lingkungan kuliah merupakan media. Secara lebih khusus pengertian media dalam proses pembelajan cenderung diartikan sebagai alat-alat grafis, photo garfis atau elekstronis untuk menangkap, memproses dan menyusun kembali informasi visual atau verbal. Menurut Rodhatul Jennah (2009:1) media pembelajaran merupakan bentuk dan saluran yang digunakan untuk menyampaikan pesan atau informasi, disampin itu sebagai pengantar, media sering disebut sebagai mediator. Mediator dapat pula mencerminkan pengertian bahwa sistem pembelajaran yang membutuhkan peralatan canggih dapat juga disebut media. Ringkasnya media pembelajaran adalah sarana untuk menyampaikan atau mengantarkan pesan-pesan dalan pembelajaran. 
Saat ini elektronik banyak digandrungi oleh kalangan anak muda, pemerintah beserta tenaga pendidikan mengambil kesempatan saat masa sekarng ini dengan membuat media denga elektronik. Banyaknya media pembelajaran dengan elekronik salah satunya yaitu e-modul. E-modul adalah sebuah program aplikasi yang dapat mengubah sebuah media pembelajaran kedalam web. Menurut Putra (2017:41) kelebihan dari penggunaan e-modul dibandingkan dengan penggunaan bahan ajar lain seperti buku konvensional yaitu lebih interaktif, karena dengan e-modul kita dapat menyisipkan suatu bahan ajar tidak hanya dalam bentuk teks saja, juga bisa dalam bentuk animasi, audio maupun video yang membuat mahasiswa menjadi lebih tertarik untuk mempelajarinya. Selain penjelasan diatas e-modul juga dapat mengelola materi pembelajaran, mengupload tugas, menerima tugas dari mahasiswa, membarikan tes/qiuz, mengelola nilai dan sebagainya.

Beberapa aspek yang harus diperhatikan dalam membuat media pembelajaran salah satunya adalah kepraktisan media. Kepraktisan media ini berkaitan dengan keterpakaian bahan perkuliahan oleh dosen dan juga mahasiswa. Bahan atau media pembelajaran dikatakan praktis jika mahasiswa dan dosen dapat menggunakan bahan secara logis dan berkesinambungan tanpa banyak masalah dalam penggunaan. Maka penelitian ini bertujuan untuk melihat praktikalitas e-modul dalam pembelajaran nail art.

\section{Pembahasan}

\section{Nail Art (Merias Kuku)}

Nail art saat ini banyak digandrungi oleh wanita, banyak wanita yang menggunakan nail art menyesuaikan dengan keadaan mereka, seperti kesesuaian dengan tempat yang akan mereka tujuan. Pengertian nail art adalah sebuah seni menggambar yang mana menjadi kanvasnya adalah kuku, kuku digambar sesuai dengan keinginan klient, untuk bisa mencocokan keinginan tersebut kita memerlukan kreativitas.

Sebelum melakukan nail art, klient diharapkan terlebih dahulu melakukan perawatan tangan dan juga kaki karena ketika kuku sudah bersih akan memudahkan perlakuan selanjutnya.

\section{Media Pembelajaran}

Aktivitas pembelajaran merupakan sistem, yang terdiri dari beberapa komponen meliputi: tujuan, isi pembelajaran, kegiatan pembelajaran, manusia (pembelajar dan pebelajar), media/ sumber belajar. Secara terorganisir komponen-komponen tersebut saling bekerja sama sesuai dengan fungsi masing-masing. Bila salah satu komponen terganggu, akan mempengaruhi kerja komponen lain sehingga hasilnya tidak sesuai lagi dengan harapan semula. pembelajaran merupakan proses yang komplek yang terintegrasi meliputi manusia, prosedur, ide, peralatan dan organisasi, untuk menganalisis masalah yang menyangkut semua aspek belajar serta merancang, melaksanakan, mengevaluasi, dan mengelola pemecahan masalah dalam rangka mencapaitujuan yang telah ditetapkan. Dari sini tampak bahwa media merupakan salah satu komponen dalam pembelajaran. Sehingga kedudukan media tidak hanya sekedar sebagai alat bantu mengajar, tetapi sebagai bagian integral dalam proses pembelajaran. Kedudukan media ini sudah jelas dalam uraian tentang hubungan antara media pembelajaran dengan komponen sistem pembelajaran sebagai wujud pemecahan masalah belajar. Bahkan kalau dikaji lebih jauh, media tidak hanya sebagai penyalur pesan yang harus dikendalikan sepenuhnya oleh sumber berupa orang, tetapi dapat juga menggantikan sebagian tugas pendidik sebagai penyaji materi pelajaran.

Dalam proses penyampaiannya media pembelaiaran dapat berfungsi dengan baik apabila media tersebut dapat digunakan secara perorangan maupun kelompok. Media pembelajaran merupakan bagian yang integral atau yang amat penting. Hubungan antara media pembelajaran dengan komponen sistem pembelajaran sebagai wujud pemecahan masalah belajar, dimana saling berkaitan antara metode, strategi dan media. Fungsi utama media pembelajaran adalah untuk tujuan instruksional, dimana informasi yang terdapat dalam media harus melibatkan siswa baik dalam bentuk mental maupun dalam bentuk aktifitas yang nyata sehingga pembelajaran dapat terjadi. Disamping untuk membangkitkan memotivasi, minat atau tindakan dan rangsangan para siswa untuk bertindak dalam kegiatan pembelajaran, juga untuk tujuan informasi (menyajikan informasi) dihadapan sekelompok mahasiswa/orang.

\section{E-Modul}

E-Modul merupakan suatu modul TIK, yang memiliki kelenihan dibadingkan dengan modul cetak adalah sifatnnya yang iteraktif memudahkan dalam pnyimpanan, memungkinkan menampilkan serta memuat gambar, audio, video dana animasi serta dilengkapi dengan tes/kuis formatif yang memiliki umpan balik otomatis dengan cepat. E-modul dikembangkan berorientasi untuk memecahakan masalah. Widiana (2016:532) dalam penelitiannya yang mana rendahnya kemampuan berfikir kreatif mahasiswa, kemampuan berpikir kreatif adalah kemampuan meng identifikasi fkta yang relevan, mengenali keterbatasan, asumsi- 
asumsi dan menentukan jawaban itu yang kurang leh mahaiswa. Dilanjutkan dengan penggunaan e-modul mahasiswa mampu mengahadapi, menganalisis permasalahan yang terjadi didalam pemebelajaran. Penggunaan e-modul berorientasi pada pemecahan masalah akan menuntun mahasiswa mencari permasalahan secara madiri dan hal ini akan memberikan suatu pengalaman yang konkret dalam pemecahan masalah, sehingga menumbuhkan dan melatih keterampilan berpikir tingkat tinggi mahasiswa.

\section{Metode}

Penelitian yang digunakan adalah penelitian pengembangan. Menggunakan metode 4-D (define, design, develop, and deseminate). Pada peneliian ini dilakukan uji coba produk untuk melihat kepraktikalitas (develop). Uji coba dilakukan kepada dua orang dosen, tiga orang kelompok kecil oleh mahasiswa dan sepuluh orang kelompok besar oleh mahasiswa di Pendidikan Tata Rias dan Kecantika UNP. Instrumen yang digunakan adalah dengan menggunakan angket.Hasil angket praktikalitas dari semua sampel dianalisis dengan rumus persentase.

\section{Hasil dan Pembahasan}

Uji praktikalitas dosen diperoleh rata-rata pada aspek kemudahan dalam penggunaan e-modul sebesar 100\% yang mana termasuk kategori sangat praktis. Uji praktikalitas oleh mahasiswa dalam kelompok kecil juga mendapatkan presentase $100 \%$ kategori sangat praktis. Uji praktikalitas oleh mahasiswa kelompok besar mendapat presentase $85 \%$ katergori praktis.

\section{Simpulan}

Berdasarkan hasil pembahasan diatas dapat kita simpulkan bahwa praktikalitas penggunaan e-modul dalam pembelajaran nail art termasuk dalam kategori sangat praktis. Pendapat diatas dapat dikatakan cocok dalam pembelajaran ini. Saran dari peneliti, untuk penelitian selanjutnya mungkin bisa melihat dari keefektifitas media, atau mungkin bisa digunakan dalam pembelajaran yang berbeda.

\section{Referensi}

Andiyana, Muhamad Arfan, Rippi Maya, and Wahyu Hidayat. "Analisis kemampuan berpikir kreatif matematis siswa smp pada materi bangun ruang." JPMI (Jurnal Pembelajaran Matematika Inovatif) 1.3 (2018): 239-248.

Jennah, Rodhatul. "Media Pembelajaran." (2009).

Putra, Komang Wisnu Baskara, I. Made Agus Wirawan, and Gede Aditra Pradnyana. "Pengembangan emodul berbasis model pembelajaran discovery learning pada mata pelajaran "sistem komputer" untuk siswa kelas x multimedia smk negeri 3 singaraja." Jurnal Pendidikan Teknologi dan Kejuruan 14.1 (2017).

Widiana, I. Wayan. "E-modul berorientasi pemecahan masalah dalam pembelajaran statistik inferensial." Prosiding Semnas Hasil Penelitian (2016). 